\title{
SYNTHESIS AND ACCUMULATION OF PUTATIVE NEUROTRANSMITTERS BY CULTURED NEURAL CREST CELLS ${ }^{1}$
}

\author{
G. D. MAXWELL, 2 P. D. SIETZ, AND C. E. RAFFORD \\ Department of Anatomy, University of Connecticut Health Center, Farmington, Connecticut 06032
}

Received November 25, 1981; Revised February 1, 1982; Accepted February 16, 1982

\begin{abstract}
The events mediating the differentiation of embryonic neural crest cells into several types of neurons are incompletely understood. In order to probe one aspect of this differentiation, we have examined the capacity of cultured quail trunk neural crest cells to synthesize, from radioactive precursors, and store several putative neurotransmitter compounds. These neural crest cultures develop the capacity to synthesize and accumulate acetylcholine and the catecholamines norepinephrine and dopamine. In contrast, detectable but relatively little synthesis and accumulation of 5hydroxytryptamine, $\gamma$-aminobutyric acid, or octopamine from the appropriate radiolabeled precursors were observed. The capacity for synthesis and accumulation of radiolabeled acetylcholine and catecholamines is very low or absent at 2 days in vitro. Between 3 and 7 days in vitro, there is a marked rise in both catecholamine and acetylcholine accumulation in the cultures. These findings suggest that, under the particular conditions used in these experiments, the development of neurotransmitter biosynthesis in trunk neural crest cells is restricted and resembles, at least partially, the pattern observed in vivo. The development of this capacity to synthesize and store radiolabeled acetylcholine and catecholamines from the appropriate radioactive precursors coincides closely with the development of the activities of the synthetic enzymes choline acetyltransferase and dopamine $\beta$-hydroxylase reported by others (Kahn, C. R., J. T. Coyle, and A. M. Cohen (1980) Dev. Biol. 77: $340-348)$.
\end{abstract}

The neurons of the dorsal root sensory ganglia, the prevertebral and paravertebral sympathetic ganglia, the parasympathetic ganglia, the enteric ganglia, and the cells of the adrenal medulla arise primarily from the cells of the embryonic neural crest. Several non-neuronal cell types also are derived from this remarkable structure (Horstadius 1950; Weston, 1970; Noden, 1978a; Le Douarin, 1980). Considerable experimental evidence supports the view that the embryonic environment can greatly influence the pattern of migration and differentiation of both neuronal and non-neuronal neural crest derivatives (Weston and Butler, 1966; Le Douarin and Teillet, 1974; Noden, 1978b, c; Bronner-Fraser et al., 1980). Our interest focuses upon the identity and control

'We thank Mark Kindy and Tom Fox, Department of Neuroscience, Children's Hospital, Boston, MA for kindly performing the high performance liquid chromatography assays. We also thank $M$. Hills for typing the manuscript and S. J. Cooperstein, S. Potashner, and B. Shur for their comments on the manuscript. This work was aided by Grant NS 16115 from the National Institutes of Health and Basil O'Connor Starter Grant 5-289 from the March of Dimes Birth Defects Foundation.

${ }^{2}$ To whom correspondence should be addressed. of the sequence of events that occur as a neural crest cell acquires the array of phenotypic properties necessary for a given type of neuron.

A number of compounds probably are used as neurotransmitters or neuromodulators by the neural crest-derived neurons in the adult. These compounds include norepinephrine in sympathetic ganglia; dopamine in sympathetic ganglia; epinephrine in sympathetic ganglia and the adrenal medulla; acetylcholine ( $\mathrm{ACh}$ ) in parasympathetic, enteric, and some sympathetic ganglia; and 5hydroxytryptamine (5-HT) in enteric ganglia (Patterson, 1978; Hokfelt et al., 1980; Gershon, 1981). In addition, several neuroactive peptides have been located in these peripheral neurons in several species (Hokfelt et al., 1980). The metabolism of these putative neurotransmitters and neuromodulators serves as a convenient phenotypic marker for the differentiation of neural crest cells into neurons. To characterize further the ontogeny and control of neuronal phenotypic expression by neural crest cells, we have examined the ability of cultured quail trunk neural crest cells to synthesize, from radiolabeled precursors, and store several putative neurotransmitter compounds. These experiments focused on two particular questions. First, which of the putative neurotransmitters 
are synthesized and accumulated by neural crest cells cultured in vitro in the absence of their normal synaptic inputs, targets, or cells from their normal embryonic environment? Second, how does the temporal appearance of the capacity of cultured neural crest cells to synthesize and accumulate these putative neurotransmitters compare with the pattern of development of neurotransmitter synthetic enzymes and catecholaminecontaining cells that has been observed previously in vivo and in vitro (Enemar et al., 1965; Allan and Newgreen, 1977; Cohen, 1977; Cochard et al., 1978; Teitelman et al., 1979; Kahn et al., 1980)? A portion of this work has been presented at the 11th Annual Meeting of the Society for Neuroscience (Maxwell et al., 1981).

\section{Materials and Methods}

Neural crest cultures. Fertilized Japanese quail eggs (Coturnix coturnix) were purchased from the Nutritional Sciences Department, University of Connecticut and were incubated at $37^{\circ} \mathrm{C}$ in a humidified, forced draft incubator (Humidaire Incubator Co.). Primary trunk neural crest cultures were prepared from stage 12 to 13 quail embryos (Zacchei, 1961). Embryos were removed from the egg and rinsed in Hanks' balanced salt solution (Gibco) buffered to $\mathrm{pH} 7.4$ with $15 \mathrm{~mm}$ HEPES (Sigma) (HBSS-HEPES). The vitelline membranes were removed with forceps and the embryos were transferred to 100-mm Petri dishes containing solidified 1\% agar (Difco). Neural tubes were dissected by the procedure of Loring et al. (1981). Briefly, the trunk portion of the embryo, medial to the lateral plate mesoderm, including the last 10 somites but excluding the remnant of the primitive streak, was removed. These pieces of trunk were incubated in $0.6 \%$ pancreatin (Gibco) at room temperature for 10 to $15 \mathrm{~min}$. Once the somites began to separate from the neural tube, the trunks were washed three times in HBSS-HEPES, pH 7.4, and the neural tubes were dissected free of the somites, notochord, and ectoderm. Neural tubes were inspected under a dissecting microscope at $\times 64$ magnification prior to plating, and neural tubes with evidence of somite, notochord, or ectoderm were either cleaned or discarded.

Neural tubes were plated and grown in a medium containing $50 \mathrm{ml}$ of Dulbecco's modified Eagle medium with $4.5 \mathrm{gm} /$ liter of glucose, $\mathrm{pH} 7.4$ (Gibco), $50 \mathrm{ml}$ of Ham's F-12 medium, pH 7.4 (Gibco), $15 \mathrm{ml}$ of horse serum (Gibco), $10 \mathrm{ml}$ of 9- to 10-day chick embryo extract (Gibco or prepared by the method of Cahn et al. (1967)), $10 \mathrm{mg}$ of gentamicin sulfate (Schering-Plough), 10,000 units of penicillin (Gibco), $10 \mathrm{mg}$ of streptomycin (Gibco), $0.5 \mu \mathrm{g}$ of $2.5 \mathrm{~S}$ nerve growth factor (NGF; Collaborative Research), $1 \mathrm{ml}$ of $0.2 \mathrm{~m} \mathrm{~L}$-glutamine (Sigma), and $1 \mathrm{ml}$ of a $100 \times$ stock vitamin mix. The vitamin mix stock contained $1 \mathrm{mg}$ of dimethyltetrahydrobiopterin (Cal. biochem), $100 \mathrm{mg}$ of ascorbic acid (Sigma), $10 \mathrm{mg}$ of glutathione (Sigma), and $20 \mathrm{ml}$ of distilled water, final pH 6.0 (Mains and Patterson, 1973). Cultures were grown in either 35-mm tissue culture dishes (Falcon) or 16- $\mathrm{mm}$ Multiwell plates (Falcon) coated with a thin film of rat tail or calf skin collagen polymerized by ammonia vapors (Ehrmann and Gey, 1956). Cell cultures were grown at $36.5^{\circ} \mathrm{C}$ in a $5 \% \mathrm{CO}_{2}$ incubator (Forma Scientific). The neural tubes were removed from primary cultures 42 to $48 \mathrm{hr}$ after plating using tungsten needles. Immediately after neural tube removal, cultures were washed and fed with fresh medium and examined using phase contrast microscopy to ensure that the neural tubes had been removed completely, leaving behind only those cells that had migrated away from the tube. Cultures were again examined carefully prior to radioactive incubations and those with any visible remaining neural tube tissue were discarded. Every 2nd day, the cultures were fed.

Secondary cultures were prepared from primary cultures after neural tube removal on the 2nd day after plating using a modification of the procedure of SieberBlum and Cohen (1980). Cells were detached using $0.025 \%$ trypsin (Gibco) and $0.01 \%$ EDTA (Sigma) in calcium- and magnesium-free Dulbecco's phosphatebuffered saline (Gibco) at room temperature while being monitored with a phase contrast microscope. When detachment of the cells was evident, trypsinization was stopped with the addition of $10 \mu \mathrm{g} / \mathrm{ml}$ of soybean trypsin inhibitor (Sigma) in growth medium. An equal volume of growth medium then was added to the cells and they were centrifuged at $600 \times g$ for $10 \mathrm{~min}$ and resuspended in growth medium. Secondary cultures were plated at 9.6 $\times 10^{4}$ cells per 16 -mm Multiwell plate for 2-day experiments and at $9.6 \times 10^{3}$ cells per Multiwell plate for experiments longer than 2 days.

Neurotransmitter metabolism. The synthesis and accumulation of presumptive neurotransmitters were determined using the method of Hildebrand et al. (1971) with some of the modifications of Mains and Patterson (1973) and Maxwell et al. (1978). Briefly, growth medium was removed and cells were preincubated for $10 \mathrm{~min}$ in L15 medium (Gibco) containing $2.1 \mathrm{gm} /$ liter of sodium bicarbonate and deficient in the appropriate precursor, $10 \%$ horse serum (Gibco), $5 \mathrm{ng} / \mathrm{ml}$ of $\mathrm{NGF}, 1 \%$ vitamin mix (see above). This medium then was removed and replaced with radioactive incubation medium which was identical except that it also contained the appropriate radiolabeled precursor compounds and $5 \times 10^{-4} \mathrm{M}$ pargyline $\mathrm{HCl}$ (Sigma) (when tyrosine, tyramine, or tryptophan was the precursor) or $10^{-4} \mathrm{M}$ neostigmine methyl sulfate (Sigma) (when choline was the precursor). Final concentrations and specific activities of precursor compounds were: $100 \mu \mathrm{M}\left[{ }^{3} \mathrm{H}\right]$ tyrosine, 8.3 to $10.6 \mathrm{Ci} / \mathrm{mmol}$; 145 to $263 \mu \mathrm{M}\left[{ }^{3} \mathrm{H}\right]$ tryptophan, 3.8 to $6.9 \mathrm{Ci} / \mathrm{mmol} ; 100$ $\mu \mathbf{M}\left[{ }^{3} \mathrm{H}\right]$ tyramine, $4.7 \mathrm{Ci} / \mathrm{mmol} ; 100 \mu \mathrm{M}\left[{ }^{3} \mathrm{H}\right]$ choline, 2.7 $\mathrm{Ci} / \mathrm{mmol} ; 100 \mu \mathrm{M}\left[{ }^{3} \mathrm{H}\right]$ glutamic acid, $9.3 \mathrm{Ci} / \mathrm{mmol}$. L-[ring 2,6- $\left.{ }^{3} \mathrm{H}\right]$ Tyrosine, 30.0 to $33.4 \mathrm{Ci} / \mathrm{mmol}$; L- $\left[\mathrm{G}-{ }^{3} \mathrm{H}\right]$ tryptophan, 3.8 to $6.9 \mathrm{Ci} / \mathrm{mmol}$; $\left[\mathrm{G}-{ }^{3} \mathrm{H}\right.$ ]tyramine, $13.6 \mathrm{Ci} / \mathrm{mmol}$; and $\left[\right.$ methyl $\left.-{ }^{3} \mathrm{H}\right]$ choline chloride, $80 \mathrm{Ci} / \mathrm{mmol}$, were purchased from New England Nuclear and L- $\left[2,3-{ }^{3} \mathrm{H}\right] \mathrm{glu}-$ tamic acid, $30.0 \mathrm{Ci} / \mathrm{mmol}$, was purchased from Amersham/Searle. The purity of isotopes was monitored by high voltage electrophoresis.

Cultures were incubated for $3 \mathrm{hr}$ at $36.5^{\circ} \mathrm{C}$ in a $5 \% \mathrm{CO}_{2}$ atmosphere. At the conclusion of the incubation, the radioactive medium was removed and the cultures were washed twice for $5 \mathrm{~min}$ each in complete growth medium. The medium then was removed and the cells were ho- 
mogenized in $60 \mu \mathrm{l}$ of $\mathrm{pH} 1.9$ formate/acetate buffer (Hildebrand et al., 1971) containing nonradioactive precursors and neurotransmitter compounds of interest (Maxwell et al., 1978). Samples were frozen and thawed twice on dry ice and then electrophoresed for 1.5 to 2.25 hr at $4,500 \mathrm{~V}$ on Whatman No. $3 \mathrm{MM}$ electrophoresis paper and processed for scintillation counting (Maxwell et al., 1978). Samples were counted at $25 \%$ efficiency on a liquid scintillation spectrometer (Packard Instruments model 3385). All values for radioactive products represent the radioactivity above background and include a correction for the amount of radioactivity found to co-migrate with the product compounds at the end of a radioactive incubation without cells. Protein was determined by the method of Bradford (1976). Background values for collagen-coated dishes incubated with medium but no cells were subtracted from cell culture protein determinations.

Glyoxylic acid catecholamine fluorescence. Catecholamine fluorescence was demonstrated using a method adapted from Furness and Costa (1975). Cultures were washed twice with HBSS-HEPES, $\mathrm{pH} 7.4$, washed once with $2 \%$ glyoxylic acid, $0.5 \%$ formaldehyde ( $37 \%$ solution) in $0.1 \mathrm{M}$ sodium phosphate buffer, $\mathrm{pH} 7.0$, and allowed to react with this glyoxylic acid solution at room temperature for $10 \mathrm{~min}$. The glyoxylic acid solution then was removed, and cultures were allowed to air dry before being heated at $100^{\circ} \mathrm{C}$ for $4 \mathrm{~min}$, coverslipped using mineral oil, and observed using a Zeiss IM 35 microscope equipped for viewing catecholamine fluorescence.

Chromatography. The identity of the catecholamine products was determined using ascending paper chromatography in a second dimension orthogonal to the direction of electrophoresis described in detail by Mains and Patterson (1973). After electrophoresis in the first dimension, the paper was dried and the region of the paper containing the catecholamines was chromatographed in the second dimension. Nonradioactive standards then were located and the paper was cut into rectangles of $2 \times 1 \mathrm{~cm}$ and processed for scintillation counting. The solvent systems used for chromatography were methylethylketone:propionic acid: water (200:65:55, v:v:v), 1-butanol:isopropanol:acetic acid:water (20:40:10:20, v:v:v:v), and phenol:0.15 N HCl (115:10, v:v). Separation of tryptophan and 5-HT was achieved using thin layer cellulose chromatography plates (Eastman) with an isopropanol:ammonia:water (10:1:1, v:v:v) solvent system (Dreyfus et al., 1977) as well as by high voltage electrophoresis.

High performance liquid chromatography (HPLC) analysis of tyrosine metabolites. The method used was that of G. J. Glover, D. E. Vaccaro, M. S. Kindy, and T. O. Fox (personal communication). At the conclusion of the incubation with $\left[{ }^{3} \mathrm{H}\right]$ tyrosine, cultures were washed twice with complete growth medium and three times with HBSS-HEPES, $\mathrm{pH}$ 7.4. Cultures then were homogenized in $200 \mu \mathrm{l}$ of $0.17 \mathrm{M}$ glacial acetic acid. Samples were analyzed using a $\mathrm{C}_{18}$ microporasil reversed phase column $(0.5 \times 33 \mathrm{~mm})$ and a model $6000 \mathrm{~A}$ pump in conjunction with a model U6K injection system (Waters). Standards were monitored at $280 \mathrm{~nm}$ using a model 440 UV detector. Samples were analyzed isocratically at room temperature 23 to $24^{\circ} \mathrm{C}$ in $80 \mathrm{~mm}$ glycine- $\mathrm{HCl}, 80$ $\mathrm{mm} \mathrm{NaCl}, \mathrm{pH}$ 3.0. The radioactive eluate was collected in $0.5-\mathrm{ml}$ fractions and processed for scintillation counting.

\section{Results \\ Cell growth and morphology}

After several days in vitro, these quail trunk neural crest cultures grown on thin collagen gels contain a heterogeneous population of cells. Cell types that can be readily distinguished under phase contrast microscopy are melanocytes, unpigmented small cells, and sometimes larger fibroblastic cells (Fig. 1) (see also Cohen and Konigsberg, 1975). Cells with the morphology of neurons are not usually distinguishable under phase contrast microscopy. This probably is duc to the fact that the number of such cells is small and they exist closely intermingled with other cell types that obscure their features (Fig. 1). Processes can be seen sometimes, although the source of the processes cannot be readily traced (see also Cohen and Konigsberg, 1975). Clusters of neural crest cells, as described by Loring et al. (1981), are present sometimes, although the conditions of these experiments are not optimal for their production (Glimelius and Weston, 1981). After processing the cultures for glyoxylic acid-induced fluorescence, catecholaminecontaining cells with neuron-like morphology are revealed (Fig. 1) (see also Cohen, 1977). Using this procedure, we have examined cultures from 3 to 11 days in vitro containing a total of more than 150 initial neural tube explants. Catecholamine-containing cells were not detectable after 3 days in vitro, but by 6 days in vitro, they were clearly visible. At 9 days in vitro, there were $253 \pm 40$ (mean \pm SEM, $N=11$ ) catecholamine-containing cells per initial neural tube explant, which represents approximately $0.2 \%$ of the total cell population. The morphology of some of the catecholamine-containing cell population also changes with age. At 5 to 6 days, the fluorescent cell body is the main feature with short fluorescent processes sometimes present, while at later times, processes are longer and more numerous. In addition, at later times, thickenings can be seen along the processes that may correspond to the varicosities observed in sympathetic neurons (Fig. 1). Smaller, more intensely fluorescent cells without significant processes also are observed (Fig. 1) (see also Cohen, 1977).

\section{Neurotransmitter synthesis and accumulation}

Acetylcholine. As shown in Table I, a significant amount of synthesis and storage of $\mathrm{ACh}$ is observed in cultures grown for 7 or 10 days in vitro. This ability to accumulate ACh from $\left[{ }^{3} \mathrm{H}\right]$ choline is evident at 2 days in vitro but remains relatively low until 5 days in vitro and it rises sharply between 5 and 7 days (Fig. 2). This increase after 5 days in vitro is evident whether ACh synthesis is normalized per initial neural tube explant, per $\mu \mathrm{g}$ of protein, or per cpm of cell-associated $\left[{ }^{3} \mathrm{H}\right]$ choline (Fig. 2; Table II). 'There is little depletion of $\left[{ }^{3} \mathrm{H}\right]$ choline or other precursors under the conditions used in these experiments (Table I). 

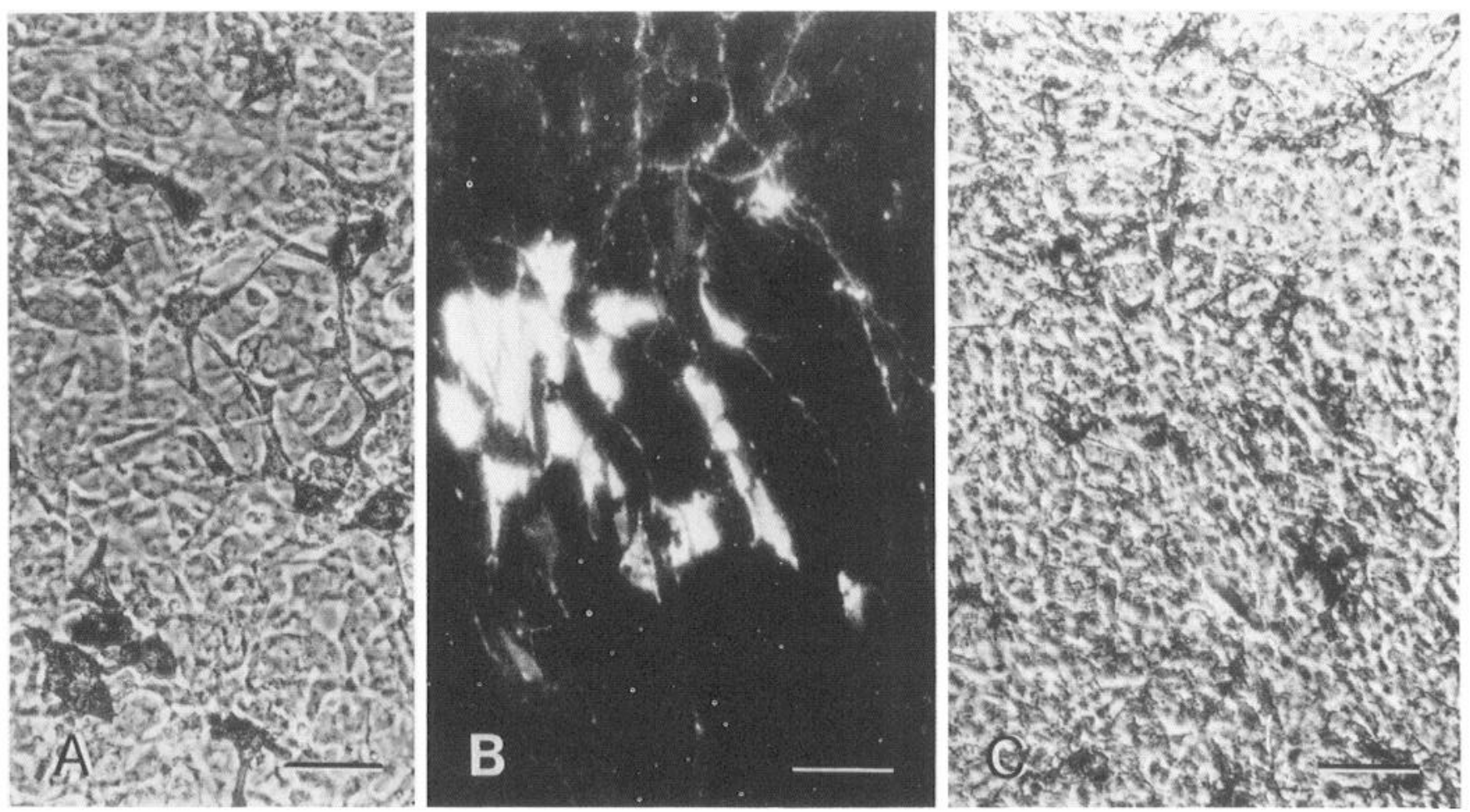

Figure 1. Morphology of primary neural crest cell cultures. A, Phase contrast photograph of a region of a living primary neural crest culture after 8 days in vitro. Melanocytes and unpigmented small cells are both visible. Scale bar, $50 \mu$ m. $B$, Photograph of a region of a primary neural crest culture, after 10 days in vitro, that has been processed for glyoxylic acid-induced fluorescence, as described under "Materials and Methods," when illuminated for catecholamine fluorescence. Fluorescent cells both with and without processes are visible. Scale bar, $50 \mu \mathrm{m}$. $C$, Phase contrast photograph of the same field shown in $B$ after processing for glyoxylic acid-induced fluorescence. Note that, although melanocytes and unpigmented cells can be seen, it is difficult to visualize the fluorescent cells shown in B. Scale bar, $50 \mu \mathrm{m}$.

TABLE I

Synthesis and accumulation of neurotransmitter candidates by primary neural crest cultures

The results shown are derived from cultures prepared and assayed as described under "Materials and Methods." The values for ${ }^{3} \mathrm{H}$ precursor and ${ }^{3} \mathrm{H}$ product represent the mean \pm SEM for the number $(N)$ of determinations indicated. The results from cultures between 7 and 10 days in vitro are pooled for all products except $\mathrm{ACh}$, for which 7- and 10-day values are indicated separately. The values for the percentage of ${ }^{3} \mathrm{H}$ precursor remaining after the incubation are the mean of duplicate determinations from 7-day-old cultures. Although values are expressed per neural tube, all neural tubes were removed after 42 to $48 \mathrm{hr}$ in vitro as described under "Materials and Methods." Catecholamines are the sum of the radioactivity co-migrating with dopamine and norepinephrine.

\begin{tabular}{|c|c|c|c|c|c|c|}
\hline \multirow[t]{2}{*}{${ }^{3} \mathrm{H}$ Precursor } & \multirow{2}{*}{$\begin{array}{c}\begin{array}{c}{ }^{3} \mathrm{H} \text { Precursor } \\
\text { in Medium after } \\
\text { Incubation }\end{array} \\
\%\end{array}$} & \multirow{2}{*}{$\begin{array}{l}\begin{array}{c}{ }^{3} \mathrm{H} \text { Precursor } \\
\text { Associated with Cells } \\
\text { after Incubation }\end{array} \\
\mathrm{cpm} / \text { neural tube }\end{array}$} & \multirow[t]{2}{*}{${ }^{3} \mathrm{H}$ Product } & \multicolumn{2}{|c|}{$\begin{array}{l}{ }^{3} \mathrm{H} \text { Product Associated with } \\
\text { Cells after Incubation }\end{array}$} & \multirow[t]{2}{*}{$N$} \\
\hline & & & & cpm/neural tube & fmol/neural tube & \\
\hline \multirow[t]{2}{*}{ Choline } & 94 & $130,681 \pm 27,983$ & ACh, 7-day & $10,374 \pm 1,415$ & $6,991 \pm 956$ & 3 \\
\hline & & $282,410 \pm 60,591$ & $\mathrm{ACh}, 10$-day & $24,879 \pm 6,188$ & $16,810 \pm 4,181$ & 5 \\
\hline Tyrosine & 90 & $802,652 \pm 106,511$ & Catecholamines & $7,124 \pm 2,821$ & $1,554 \pm 615$ & 9 \\
\hline Tryptophan & 97 & $703,279 \pm 157,675$ & $5-\mathrm{HT}$ & $168 \pm 104$ & $61 \pm 37$ & 7 \\
\hline Glutamate & 80 & $286,979 \pm 34,097$ & GABA & $448 \pm 115$ & $87 \pm 22$ & 5 \\
\hline
\end{tabular}

Catecholamines. Significant synthesis of catecholamines also is seen when cultures are grown for 7 to 10 days in vitro (Table I). The identity of the main products as norepinephrine and dopamine was confirmed by ascending chromatography in a second dimension following electrophoresis and by high performance liquid chromatography. Ascending chromatography reveals that the majority of the counts in the first dimension co-migrate with norepinephrine and dopamine (Fig. 3). High performance liquid chromatography of four samples of 9day-old cultures incubated with $\left[{ }^{3} \mathrm{H}\right]$ tyrosine also showed $\left[{ }^{3} \mathrm{H}\right]$ norepinephrine and $\left[{ }^{3} \mathrm{H}\right]$ dopamine in three of the samples and $\left[{ }^{3} \mathrm{H}\right]$ norepinephrine alone in one of the samples. An example of an experiment in which $\left[{ }^{3} \mathrm{H}\right]$ norepinephrine and $\left[{ }^{3} \mathrm{H}\right]$ dopamine are detected is shown in Figure 4.

Catecholamine synthesis and accumulation in primary cultures are not evident until 3 days in vitro and rise rapidly between 3 and 7 days (Fig. 5). As with $\mathrm{ACh}$ synthesis, this increase is apparent regardless of the method used to compute the data (Fig. 5; Table II). After 7 days in vitro, the synthesis and accumulation of cate- 


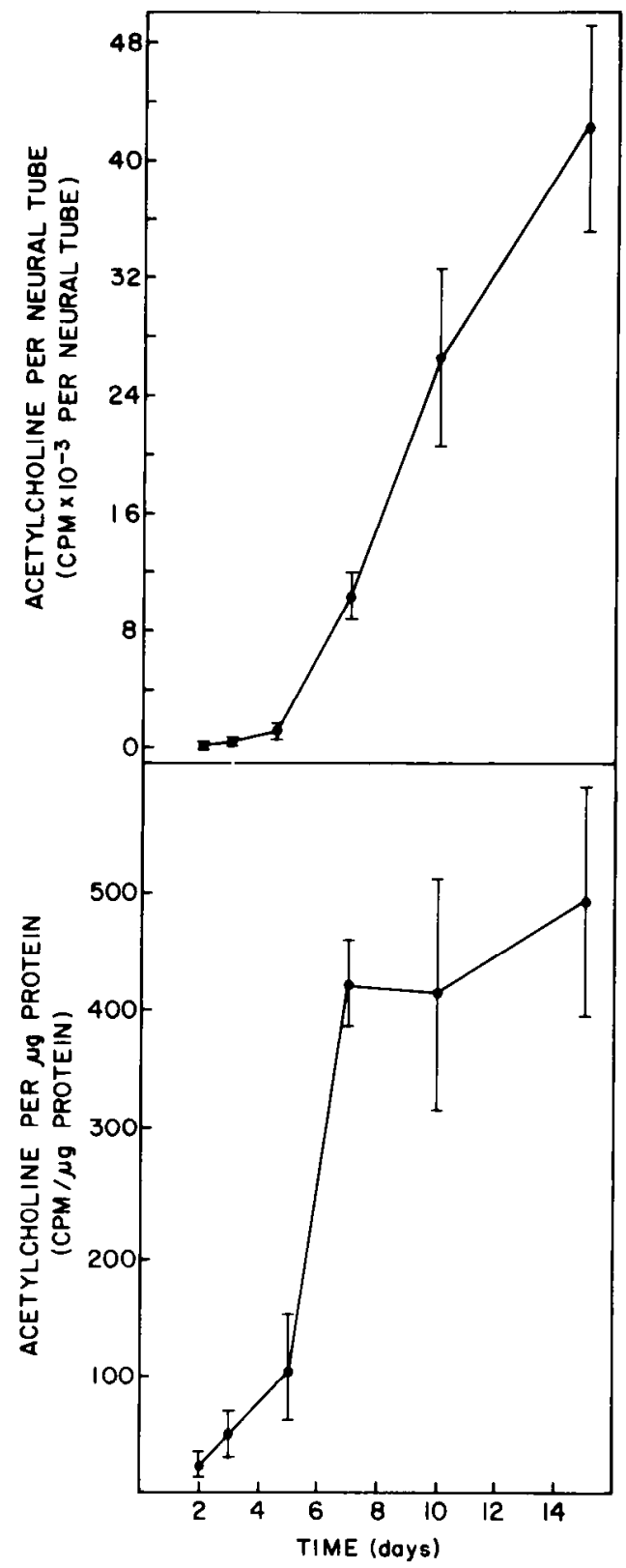

Figure 2. ACh synthesis and accumulation in primary trunk neural crest cultures. Cultures were prepared as described under "Materials and Methods." The values represent the mean \pm SEM of three to five determinations. In the top panel, $\mathrm{ACh}$ accumulation is expressed per neural tube explant put into culture. In the bottom panel, ACh accumulation is expressed per $\mu \mathrm{g}$ of protein. All neural tubes were removed at 42 to $48 \mathrm{hr}$ in vitro prior to the first time point. For 2- and 3-day experiments, 7 to 10 neural tubes were used per culture, while in the later experiments, 2 to 4 neural tubes were used per culture.

cholamines per $\mu \mathrm{g}$ of protein do not continue to increase and may, in fact, decline. One likely explanation for this change is an increase in cellular protein not associated with catecholamine synthesis.

When secondary cultures are prepared from 2-day-old primary cultures, catecholamine synthesis and accumulation also develop with a pattern very similar to that seen in primary cultures (Fig. 6). There is a rise in synthesis between 3 and 8 days in vitro and a decline

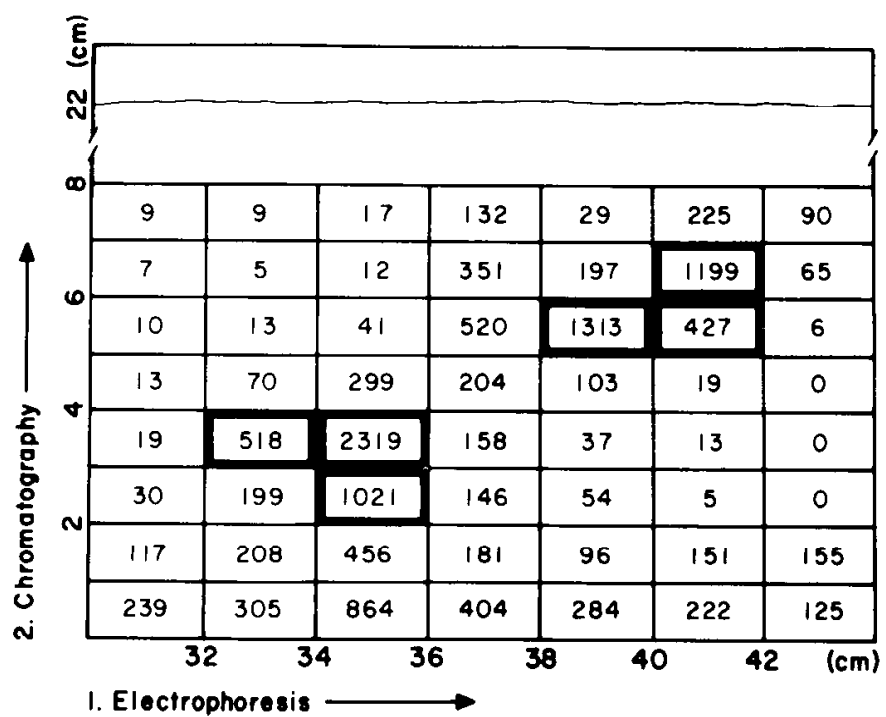

Figure 3. Identity of catecholamine products produced in neural crest cultures. This is a profile of the radioactivity obtained when $\left[{ }^{3} \mathrm{H}\right]$ tyrosine products from 9-day-old primary neural crest cultures were separated by high voltage electrophoresis at $\mathrm{pH} 1.9$ in direction 1 and by ascending paper chromatography in direction 2 in the 1-butanolisopropranol:acetic acid:water (20:40:10:20, v:v:v:v) solvent system as described under "Materials and Methods." The numbers in direction 1 indicate the distance from the origin of electrophoresis and the numbers in direction 2 indicate the distance from the origin of chromatography. The numbers in the rectangles indicate counts per min above a background of $32 \mathrm{cpm}$. The entire chromatogram was analyzed from the origin to the solvent front, indicated by the irregular line parallel to the top of the figure. No counts above background were found between 8 and $22 \mathrm{~cm}$ in the chromatographic dimension over the region shown. The outlined squares on the left indicate the position of a norepinephrine standard and those on the right show a dopamine standard. Greater than $70 \%$ of the radioactivity found on a parallel lane in the first dimension was recovered in the six outlined squares on the chromatogram. Similar results were obtained using the two other solvent systems given under "Materials and Methods."

thereafter when the data are expressed per $\mu$ g of protein. The synthesis and storage of catecholamines per $\mu \mathrm{g}$ of protein in secondary cultures achieve values similar to those seen in primary cultures. The variability seen in primary cultures is considerably reduced when secondary cultures are used.

5-HT. Very small amounts of 5-HT synthesis and accumulation are observed in trunk neural crest cultures grown for 7 to 10 days in vitro (Table I). The observed synthesis and storage, however, are variable, with some cultures showing no 5-HT accumulation, while others show accumulation above background. We thought that the positive cases of $5-\mathrm{HT}$ might be due to the inclusion of neural crest from more anterior levels of the embryo. Therefore, we assayed six neural crest cultures prepared from the vagal region of stage 8 to 9 embryos. It is the vagal region that probably gives rise to some of the 5HT-containing enteric neurons in vivo (Le Douarin and Teillet, 1974; Gershon, 1981). These vagal cultures grown for 8 days did not exhibit levels of 5-HT synthesis and accumulation above background. Cultures of embryonic 


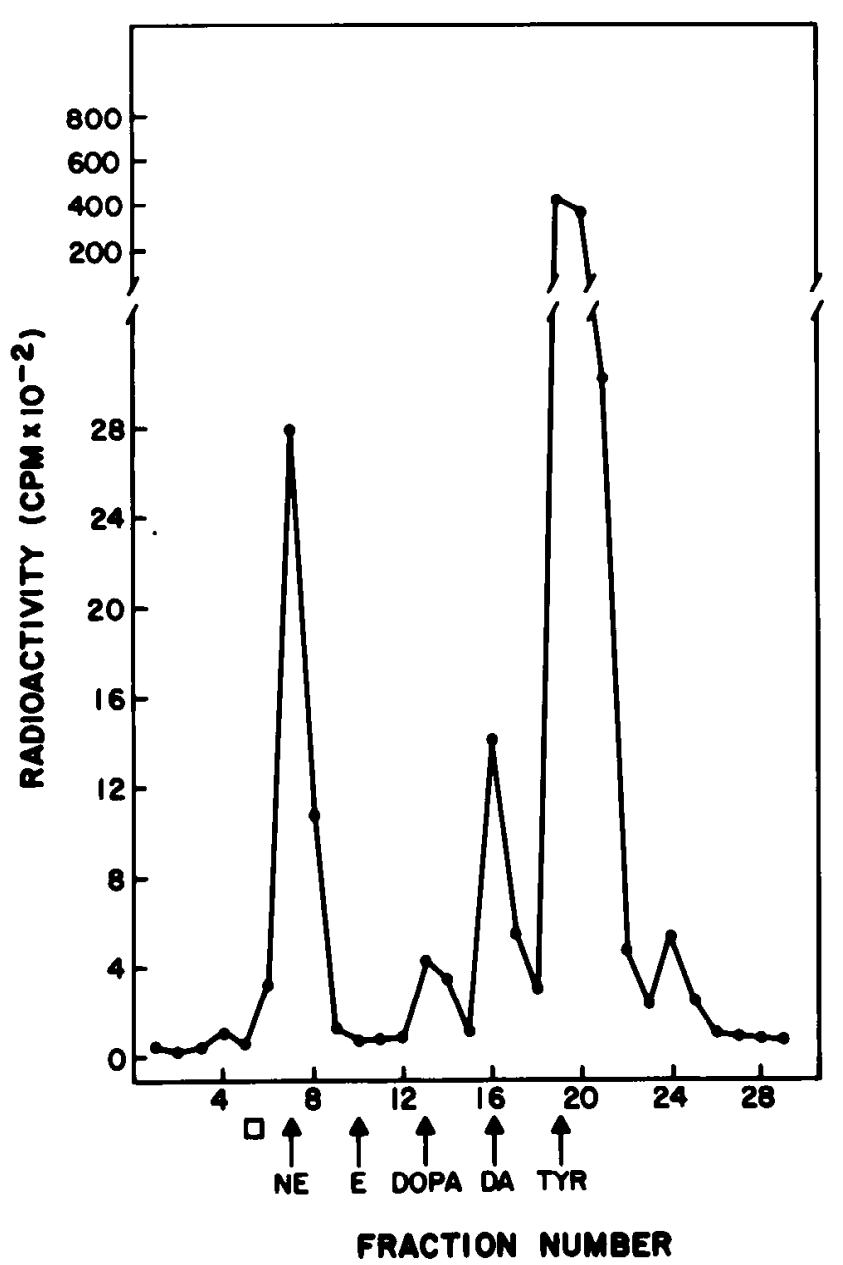

Figure 4. Identity of $\left[{ }^{3} \mathrm{H}\right]$ tyrosine metabolites in a primary neural crest culture. Primary neural crest cultures were prepared and analyzed after 9 days in vitro on a $\mathrm{C}_{18}$ microporasil reverse phase HPLC column as described under "Materials and Methods." The open square represents the breakthrough or void volume and the positions of norepinephrine $(N E)$, epinephrine $(E)$, dihydroxyphenylalanine ( $D O P A)$, dopamine (DA), and tyrosine (TYR) standards are indicated. A small peak of about $300 \mathrm{cpm}$ is seen sometimes at the breakthrough when the breakthrough and $N F$ are completely resolved.

day 12 quail brainstem grown for 8 days in vitro were, however, able to accumulate material co-migrating with $\left[{ }^{3} \mathrm{H}\right] 5$-HT from $\left[{ }^{3} \mathrm{H}\right]$ tryptophan.

Phenolamines. In general, when tyrosine was used as the precursor, there was little, if any, synthesis of material co-migrating with tyramine, octopamine, or synephrine. When tyramine was used as precursor, only small quantities of material co-migrating with octopamine were detected (Table I).

$G A B A$. When $\left[{ }^{3} \mathrm{H}\right]$ glutamate was used as a precursor, little $\left[{ }^{3} \mathrm{H}\right] \mathrm{GABA}$ was accumulated in trunk neural crest cultures (Table I). Parallel cultures in which the neural tube explants were not removed were able to synthesize an average of $5,022 \mathrm{cpm}$ per neural tube that co-migrated with GABA. The amount of $\left[{ }^{3} \mathrm{H}\right]$ glutamate associated with cells was only $20 \%$ greater in these cultures containing neural tubes than in the neural crest cultures from which the neural tubes were removed, while $\left[{ }^{3} \mathrm{H}\right] \mathrm{GABA}$ was increased by an order of magnitude. Cultures of embryonic day 10 quail cerebellum and cortex also dem-

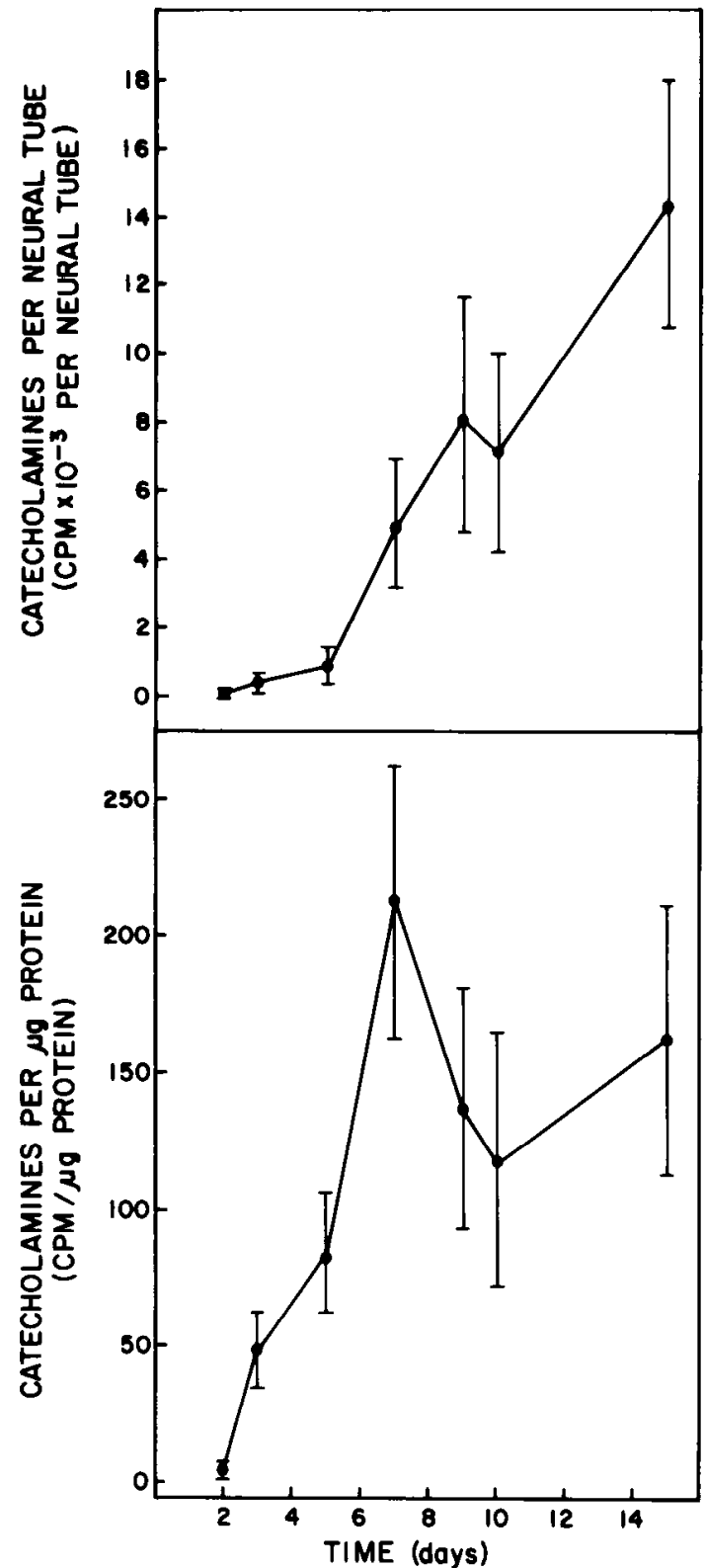

Figure 5. Catecholamine synthesis and accumulation in primary trunk neural crest cultures. Cultures were prepared as described under "Materials and Methods." The values represent the mean \pm SEM of three to five determinations. In the top panel, catecholamine accumulation is expressed per neural tube put into culture. In the bottom panel, catecholamine accumulation is expressed per $\mu \mathrm{g}$ of protein. All neural tubes were removed at 42 to $48 \mathrm{hr}$ in vitro, prior to the first time point. For 2- and 3-day experiments, 7 to 10 neural tube explants were used per culture, while in later experiments, 2 to 4 neural tubes were used per culture.

onstrated significant synthesis of $\left[{ }^{3} \mathrm{H}\right] \mathrm{GABA}$ from $\left[{ }^{3} \mathrm{H}\right]$ glutamate after 7 days in vitro. Thus, the absence of $\left[{ }^{3} \mathrm{H}\right]$ GABA product in trunk neural crest cultures probably is not due to the experimental protocol used.

\section{Discussion}

\section{Spectrum of neurotransmitter expression}

Our experiments demonstrate that quail trunk neural crest cells cultured in the absence of exogenously added 


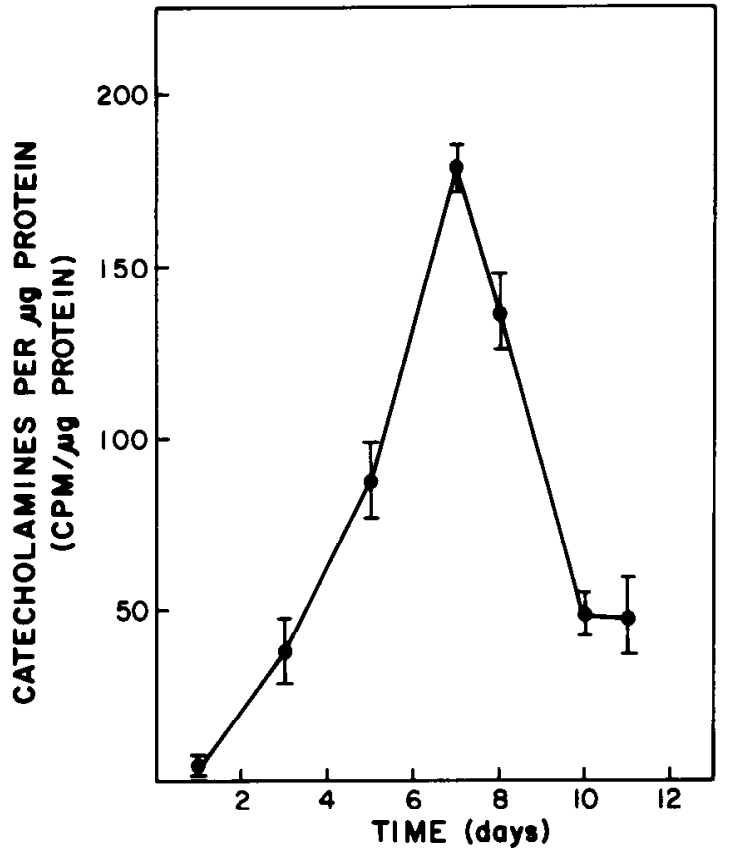

Figure 6. Catecholamine synthesis and accumulation in secondary trunk neural crest cultures. Cultures were prepared from primary cultures as described under "Materials and Methods." The values represent the mean \pm SEM of three to five separate determinations.

TABLE II

Ratio of ${ }^{3} \mathrm{H}$ product to ${ }^{3} \mathrm{H}$ precursor as a function of time in culture

The ratios of ${ }^{3} \mathrm{H}$-catecholamines to cell-associated $\left[{ }^{3} \mathrm{H}\right]$ tyrosine and $\left[{ }^{3} \mathrm{H}\right] \mathrm{ACh}$ to cell-associated $\left[{ }^{3} \mathrm{H}\right]$ choline at the end of the incubation of trunk quail neural crest primary cultures at 3 and 7 days in vitro are given. The values are the mean \pm SEM of triplicate samples.

\begin{tabular}{ccc} 
Thime In Vitro & $\begin{array}{c}\text { H-Catecholamine/ } \\
{\left[{ }^{3} \mathrm{H}\right] \text { Tyrosine }} \\
\left(\times 10^{2}\right)\end{array}$ & $\begin{array}{c}{\left[{ }^{3} \mathrm{H}\right] \mathrm{ACh} /\left[{ }^{3} \mathrm{H}\right] \mathrm{Choline}} \\
\left(\times 10^{2}\right)\end{array}$ \\
\hline
\end{tabular}

days

$\begin{array}{lll}3 & 0.1 \pm 0.06 & 0.6 \pm 0.1\end{array}$

$\begin{array}{lll}7 & 1.3 \pm 0.3 & 7.9 \pm 1.0\end{array}$

non-neural crest cells develop the ability to synthesize and accumulate significant quantities of $\mathrm{ACh}$ and the catecholamines norepinephrine and dopamine. In contrast, we find relatively little synthesis and accumulation of 5-HT, GABA, or octopamine from the appropriate radiolabeled precursor compounds after 7 to 10 days in vitro. These results suggest that, at least under the particular set of conditions used in these experiments, the development of neurotransmitter metabolism in trunk neural crest cells in vitro is restricted and resembles, at least partially, the pattern observed in vivo.

The assay method that we have used requires that cells be able to take up the appropriate precursor compound, convert it to product, and accumulate detectable levels of the product (Hildebrand et al., 1971; Mains and Patterson, 1973; Maxwell et al., 1978). Successful detection of substantial amounts of product requires the presence of the appropriate uptake systems, synthetic enzymes, cofactors, as well as a storage mechanism. Failure to fulfill any one of these conditions could result in the inability to detect significant amounts of radiolabeled product. In our hands, as little as $10^{-14} \mathrm{~mol}$ of product can be detected reliably using this method. We find that considerable amounts of radiolabeled precursors are associated with the cells at the end of the incubation (Table I). Also, there is very little depletion of precursor from the medium during our incubations (Table I). Thus, our inability to detect large amounts of 5-HT, GABA, or octopamine probably is not due to either depletion of the precursor or failure of the precursor to enter the cell. It also is not due to the absence of cofactors since cofactors for the various neurotransmitter synthetic enzymes are either present in the culture medium or have been added to it. Inhibitors of degradative enzymes were present for all products with the exception of GABA. This leaves open the possibility that GABA might be made and then rapidly degraded in neural crest cells prior to being sequestered for storage. The fact that GABA and 5-HT accumulation can be demonstrated under our experimental conditions using other cell types known to metabolize this compound (see text of "Results") indicates that the conditions of cell culture or incubation are not incompatible with the synthesis and accumulation of these two neurotransmitter candidates. These facts taken together suggest that our results can best be interpreted to mean that the particular environment constituted by the in vitro conditions used is permissive for the development of cells that can synthesize and store significant amounts of ACh and catecholamines but little or no 5-HT, octopamine, or GABA.

Our biochemical data on neurotransmitter metabolism cannot provide information about the cell populations responsible for such activities. Histochemical information about the cells that synthesize ACh is not available. In the case of the catecholamines, data from our own cultures and those of others suggest that a relatively small minority of the total cells may be responsible for the observed catecholamine accumulation. The fraction of histochemically detectable catecholamine-containing cells in the cultures is in the range of 0.1 to $1 \%$ of the total cells in the culture (see "Results" and Sieber-Blum and Cohen, 1980). While some cells may accumulate catecholamines that are biochemically detectable but not above the threshold for histochemistry, especially prior to 6 days in vitro, it seems likely that most catecholamine biosynthesis is being conducted by a relatively small population of cells in the cultures. Our own data at the light microscopic level and the data of Cohen (1977) at the light and electron microscopic levels suggest that at least two morphologically distinct catecholamine-containing cell types exist in these cultures and are responsible for the observed catecholamine biosynthesis. One is similar to the principal cells in sympathetic ganglia, while the other resembles at least one class of small, intensely fluorescent cells found in these ganglia (Cohen, 1977). It has been suggested that these two cell types may be the immediate descendants of a common precursor cell type (Landis and Patterson, 1981). Since our biochemical data are derived from heterogeneous cell populations, we cannot know if individual cells are producing both ACh and catecholamines in our cultures.

These results support and extend the previous findings that histochemically detectable catecholamine-contain- 
ing cells and dopamine $\beta$-hydroxylase and choline acetyltransferase enzyme activities develop in trunk neural crest cultures (Cohen, 1977; Kahn et al., 1980). Our results differ somewhat from those reported very recently by Fauquet et al. (1981). They indicate that trunk quail neural crest cultures initiated from neural tube explants from stage 9 to 10 embryos and grown for 7 days on tissue culture plastic in the presence of $15 \%$ fetal calf serum and $2 \%$ chick embryo extract were able to synthesize and store only very small amounts of catecholamines and $\mathrm{ACh}$, while cultures in which horse serum replaced fetal calf serum only synthesized ACh (see Table II in Fauquet et al., 1981). Choline and tyrosine, the only precursors examined, were present at a final concentration of $15 \mu \mathrm{M}$, in contrast to $100 \mu \mathrm{M}$ in the present experiments. Differences in the developmental stage of the embryos used, the lower concentration of embryo extract in their culture medium, the reduced concentration of radiolabeled precursors, differences in substrate, and variation in lots of sera and embryo extract may explain the differences between our results and those of Fauquet et al. (1981).

While our results support the notion that neural crest cells can develop the capacity to synthesize and store $\mathrm{ACh}$ and catecholamines without continued interaction with non-neural crest cells, it is also clear that the neurotransmitter metabolism of neural crest cells in vitro can be altered by changes in the environment. The growth of neural crest cells with heterologous cell types (Cohen, 1972; Norr, 1973; Teillet et al., 1978; Fauquet et al., 1981), in the presence of extracellular material from embryonic cells (Loring et al., 1979; Sieber-Blum and Cohen, 1980), with fibronectin (Sieber-Blum et al., 1981), with heart-conditioned medium (Sieber-Blum et al., 1979), and with different sera (Greenberg and Schrier, 1977; Fauquet et al., 1981) all have been reported to influence the metabolism of catecholamines and/or acetylcholine. Whether other changes in the expression of other neurotransmitter candidates may occur under such circumstances remains to be determined.

\section{Temporal pattern of neurotransmitter expression}

Catecholamines. The developmental pattern of the acquisition of catecholamine and $\mathrm{ACh}$ synthesis is of considerable interest. Catecholamine synthesis and accumulation are absent or very low at 2 days in vitro and then rise sharply between 2 and 7 days in culture. These data coincide quite closely with the onset of dopamine $\beta$-hydroxylase activity reported by Kahn et al. (1980). In vivo, the first catecholamine-containing cells can be detected histochemically in the trunk primary sympathetic chain of the chick at 3.5 days (Enemar et al., 1965; Allan and Newgreen, 1977). Since our neural crest cultures are initiated from 2-day embryos and significant catecholamine metabolism is not seen for at least 3 days, it appears that in vitro catecholamine development is somewhat behind the in vivo schedule. This is perhaps at least partially due to the disruption caused by establishing the cells in culture. In the rat embryo, the onset of immunoreactivity to tyrosine hydroxylase and dopamine $\beta$ hydroxylase and the presence of catecholamine-containing cells all occur within at least hours of one another in the primary sympathetic chain (Cochard et al., 1978; Teitelman et al., 1979). These results suggest that, in vivo, the catecholamine biosynthetic pathway is activated in a concerted fashion. Our in vitro results from quail neural crest cultures taken together with the results of Kahn et al. (1980) are consistent with such a notion. It should be noted that, in our experience, catecholamine accumulation can be detected biochemically 1 or 2 days prior to the time when it can be detected histochemically. This presumably reflects the relative sensitivities of the two methods.

Catecholamine synthesis also develops in secondary cultures prepared from primary cultures after 2 days in vitro (Fig. 6). However, in these secondary cultures, development of catecholamine accumulation occurs as if the cells start without any prior history of development. This suggests that the developmental program of the cells is retarded somewhat by exposure to protease and plating of the cells, as is perhaps true in the primary cultures. The pattern and extent of catecholamine accumulation are very similar to those seen in the primary culture, with a decline after 8 days in vitro more evident than in primary cultures. The variability of catecholamine accumulation is reduced considerably in secondary cultures when compared to primary cultures (Fig. 6).

It is of interest to note that, in both chick and quail trunk neural crest primary cultures, melanocyte differentiation increases dramatically between 3 and 7 days after neural tubes are put into culture (Maxwell, 1976; Loring et al., 1981). Since tyrosine is the precursor for both the catecholamines and melanin, their similar pattern of temporal expression may be relevant to the mechanism by which phenotypic expression is regulated.

$A C h$. ACh synthesis and accumulation in neural crest cultures are low for the first 5 days in culture and then rise rapidly (Fig. 2). These data agree well with the data on choline acetyltransferase activity of Kahn et al. (1980). It is of interest that quail cranial neural crest cells can synthesize and store ACh during and even prior to their migration (Smith et al., 1979). Differences in protocols and data computation make it difficult to compare their cranial neural crest results directly with our own on trunk neural crest cells. Methods that would allow the identification of the cell populations responsible for this ACh synthesis and accumulation would aid our understanding of this aspect of neural crest cell development. In particular, it would be of interest to know if cranial and trunk neural crest cells differ in their early expression of cholinergic traits. It has been suggested that early cholinergic expression may play a role in the development of several neuronal types (Smith et al., 1979).

\section{Conclusions}

From our experiments, two major conclusions emerge. The first is that trunk neural crest cells in vitro under one specific set of conditions express a spectrum of neurotransmitter candidate synthesis and accumulation that resembles that expressed by developing neural crest-derived neurons in vivo. This expression occurs without the presence of cells from the embryonic environment, such as somitic mesenchyme and notochord, and without the normal presynaptic inputs or postsynaptic targets. Com- 
ponents present in the medium may replace some of the molecules normally encountered by neural crest cells in vivo. Identification of the components in the medium that permit the development of the observed neurotransmitter synthesis and accumulation would be of considerable interest.

The second conclusion is that the development of ACh and catecholamine accumulation starts at very low levels in these cultures and increases sharply with time. This increase coincides closely with the development of activities of the appropriate synthetic enzymes reported by Kahn et al. (1980). Thus, there is no significant lag before these enzyme activities can be used by intact cells to synthesize and accumulate transmitter. This suggests that all of the cellular functions necessary for the biosynthesis and storage of ACh and catecholamines develop in rapid succession. Whether other aspects of neuronal function, such as electrical excitability and neurotransmitter release, also develop concomitantly with neurotransmitter biosynthetic functions is not known. Also unknown is the relationship of $\mathrm{ACh}$ and catecholamine biosynthesis to the development of other potential neurotransmitters or neuromodulators, such as peptides.

\section{References}

Allan, I. J., and D. R. Newgreen (1977) Catecholamine accumulation in neural crest cells and the primary sympathetic chain. Am. J. Anat. 149: 413-421.

Bradford, M. M. (1976) A rapid and sensitive method for the quantitation of microgram quantities of protein utilizing the principle of protein-dye binding. Anal. Biochem. 72: 248-254.

Bronner-Fraser, M., M. Sieber-Blum, and A. M. Cohen (1980) Clonal analysis of the avian neural crest: Migration and maturation of mixed neural crest clones injected into host chicken embryos. J. Comp. Neurol. 193: 423-434.

Cahn, R. D., H. G. Coon, and M. B. Cahn (1967) Cell culture and cloning techniques. In Methods in Developmental Biol. $o g y$, F. H. Wilt and N. K. Wessels, eds., pp. 493-530, Thomas Y. Crowell Co., New York.

Cochard, P., M. Goldstein, and I. B. Black (1978) Ontogenic appearance and disappearance of tyrosine hydroxylase and catecholamines in the rat embryo. Proc. Natl. Acad. Sci. U. S. A. $75: 2986-2990$.

Cohen, A. M. (1972) Factors directing the expression of sympathetic nerve traits in cells of neural crest origin. J. Exp. Zool. 179: 169-192.

Cohen, A. M. (1977) Independent expression of the adrenergic phenotype by neural crest cells in vitro. Proc. Natl. Acad. Sci. U. S. A. 74: 2899-2903.

Cohen, A. M., and I. R. Konigsberg (1975) A clonal approach to the problem of neural crest determination. Dev. Biol. 46: 262-280.

Dreyfus, C. F., M. B. Bornstein, and M. D. Gershon (1977) Synthesis of serotonin by neurons of the myenteric plexus in sicu and in organotypic tissue culture. Brain Res. 128: 125139.

Ehrmann, R. L., and G. O. Gey (1956) The growth of cells on a transparent gel of reconstituted rat-tail collagen. J. Natl. Cancer Inst. 16: 1375-1403.

Enemar, A., B. Falck, and R. Iakanson (1965) Observation on the appearance of norepinephrine in the sympathetic nervous system of the chick embryo. Dev. Biol. 11: 268-283.

Fauquet, M., J. Smith, C. Ziller, and N. M. Le Douarin (1981) Differentiation of autonomic neuron precursors in vitro: Cholinergic and adrenergic traits in cultured neural crest cells. J. Neurosci. 1: 478-492.
Furness, J. B., and M. Costa (1975) The use of glyoxylic acid for the fluorescence histochemical demonstration of peripheral stores of noradrenaline and 5-hydroxytryptamine in whole mounts. Histochemistry 41: 335-352.

Gershon, M. D. (1981) The enteric nervous system. Annu. Rev. Neurosci. 4: 229-272.

Glimelius, B., and J. A. Weston (1981) Analysis of developmentally homogeneous neural crest cell populations in vitro. III. Role of culture environment in cluster formation and differentiation. Cell Differ. 10: 57-67.

Greenberg, J. M., and B. K. Schrier (1977) Development of choline acetyltransferase activity in chick cranial neural crest cells in culture. Dev. Biol, 61: 86-93.

Hildebrand, J. G., D. L. Barker, E. Herbert, and E. A. Kravitz (1971) Screening for neurotransmitters: A rapid radiochemical procedure. J. Neurobiol. 2: 231-246.

Hokfelt, T., O. Johansson, A. Ljungdahl, J. M. Lundberg, and M. Schultzberg (1980) Peptidergic neurons. Nature 284: 515521.

Horstadius, S. (1950) The Neural Crest, Hafner Publishing Co., New York.

Kahn, C. R., J. T. Coyle, and A. M. Cohen (1980) Head and trunk neural crest in vitro: Autonomic neuron differentiation. Dev. Biol. 77: 340-348.

Landis, S. C., and P. H. Patterson (1981) Neural crest cell lineages. Trends Neurosci. 4: 172-175.

Le Douarin, N. M. (1980) Migration and differentiation of neural crest cells. Curr. Top. Dev. Biol. 16: 31-85.

Le Douarin, M. M., and M. -A. M. Teillet (1974) Experimental analysis of the migration and differentiation of neuroblasts of the autonomic nervous system and of neuroectodermal derivatives, using a biological cell marking technique. Dev. Biol. 41: 162-184.

Loring, J., B. Glimelius, and J. A. Weston (1979) Substrate of extracellular matrix components affect the choice and expression of neural crest phenotypes. J. Cell Biol. 83: 40a.

Loring, J., B. Glimelius, C. A. Erickson, and J. A. Weston (1981) Analysis of developmentally homogeneous neural crest cell populations in vitro. I. Formation, morphology, and differentiative behavior. Dev. Biol. 82: 86-94.

Mains, R. E., and P. H. Patterson (1973) Primary cultures of dissociated sympathetic neurons. I. Establishment of longterm growth in culture and studies of differentiated properties. J. Cell. Biol. 59: 329-345.

Maxwell, G. D. (1976) Cell cycle changes during neural crest cell differentiation in vitro. Dev. Biol. 49: 66-79.

Maxwell, G. D., J. F. Tait, and J. G. Hildebrand (1978) Regional synthesis of neurotransmitter candidates in the CNS of the moth Manduca sexta. Comp. Biochem. Physiol. (C) 61: 109119.

Maxwell, G. D., P. D. Sietz, and C. E. Rafford (1981) Development of neurotransmitter synthesis and accumulation in primary and secondary neural crest cultures. Soc. Neurosci. Abstr. 7: 399.

Noden, D. M. (1978a) Interactions directing the migration and cytodifferentiation of avian neural crest cells. In Specificity of Embryological Interactions, D. Garrod, ed., pp. 5-49, Chapman and Hall, London.

Noden, D. M. (1978b) The control of avian cephalic neural crest. cytodifferentiation. I. Skeletal and connective tissues. Dev. Biol. 67: 296-312.

Noden, D. M. (1978c) The control of avian cephalic neural crest cytodifferentiation. II. Neural tissues. Dev. Biol. 67: 313-329.

Norr, S. C. (1973) In vitro analysis of sympathetic neuron differentiation from chick neural crest cells. Dev. Biol. 34: 16-38.

Patterson, P. H. (1978) Environmental control of autonumic neurotransmitter functions. Annu. Rev. Neurosci. 1: 1-17. 
Sieber-Blum, M., and A. M. Cohen (1980) Clonal analysis of quail neural crest cells: They are pluripotential and differentiate in vitro in the absence of non-neural crest cells. Dev. Biol. 80: 96-106.

Sieber-Blum, M., C. R. Kahn, and A. M. Cohen (1979) Influence of heart conditioned medium on quail neural crest cells. J. Cell Biol. 83: 30a.

Sieber-Blum, M., F. Sieber, and K. M. Yamada (1981) Cellular fibronectin promotes adrenergic differentiation of quail neural crest cells in vitro. Exp. Cell Res. 133: 285-295.

Smith, J., M. Fauquet, C. Ziller, and N. M. Le Douarin (1979) Acetylcholine synthesis by mesencephalic neural crest cells in the process of migration in vivo. Nature 282: 852-855.

Teillet, M. A., P. Cochard, and N. M. Le Douarin (1978) Relative roles of the mesenchymal tissues and of the complex neural tube-notochord on the expression of adrenergic metabolism in neural crest cells. Zoon 6: 115-122.

Teitelman, G., H. Baker, T. M. Joh, and D. J. Reis (1979) Appearance of catecholamine-synthesizing enzymes during development of rat sympathetic nervous system: Possible role of tissue environment. Proc. Natl. Acad. Sci. U. S. A. 76: 509-513.

Weston, J. A. (1970) The migration and differentiation of neural crest cells. Adv. Morphog. 8: 41-114.

Weston, J. A., and S. L. Butler (1966) Temporal factors affecting localization of neural crest cells in the chicken embryo. Dev. Biol. 14: 246-266.

Zacchei, A. M. (1961) Lo sviluppo embrionale della quaglia giapponese (Coturnix coturnix japonica T.e s.). Arch. Ital. Anat. Embriol. 66: 36-62. 